\title{
EFFECT OF AN ORAL CONTRACEPTIVE AGENT ON LACTATION-DIFFERENTIAL RESPONSE IN THREE SPECIES OF ANIMALS
}

\author{
USHA M. JOSHI AND SHANTA S. RAO \\ Reproductive Physiology Unit, Indian Council of Medical Research, \\ Seth G. S. Medical College Compound, Parel, Bombay
}

(Received 26th April 1967)

\begin{abstract}
Summary. The effect of Enovid, the well-known contraceptive agent, on the lactation performance has been studied in the mouse, the rat and the rabbit. Two dose levels were employed, one corresponding to twice the human dose, on the basis of $\mathrm{mg} / \mathrm{kg}$ body weight and the other equivalent to twenty times the human dose. Growth curve of the litter was used as an index of efficacy of lactation. It was observed that, in rats, the steroid at both the dose levels caused 10 to $20 \%$ inhibition in growth rate of the young, while in rabbits there was an enhancement. The compound did not seem to have any effect on the lactation of mice. The amount of inhibition or enhancement was not related to the dose employed. The reasons for the differential response in the three species have been discussed.
\end{abstract}

\section{INTRODUCTION}

It has already been demonstrated by us (Joshi \& Rao, 1966) that Enovid, an oral progestational steroid, when fed to lactating rats from the 2nd day post partum until weaning, caused a slight inhibition of lactation in this species. The growth of the litter was taken as an index for the efficacy of lactation. Further, the young born to the mothers fed with $50 \mu \mathrm{g}$ Enovid/day showed almost the same inhibition as those administered $500 \mu \mathrm{g}$ of the steroid. This indicated that the inhibition was not proportional to the dose. It was of very great interest to find out whether inhibition of lactation occurs in other species besides the rat. The study was therefore extended to include the mouse and the rabbit.

\section{MATERIAL AND METHODS}

Rats of Wistar Strain, mice of Swiss Strain and random-bred rabbits from the Haffkine Institute animal colony were used for this study. All animals were maintained under standard conditions of food and housing.

In the case of mice and rats, the litters were reduced to six young each, on the 2 nd day post partum, while in the case of the rabbit, the litter was reduced to three young. 
The females in the control group were fed with $0 \cdot 1 \mathrm{ml}$ propylene glycol in the case of the mouse and the rat, whereas $1 \mathrm{ml}$ propylene glycol was used in the case of the rabbit. In the experimental group, the females received the calculated dose of Enovid, dissolved in the same volume of propylene glycol.

The daily dose of Enovid used for the three species was as follows: Mouse. Two Groups (six females/group) fed with 5 and $50 \mu \mathrm{g}$ Enovid, respectively. A dose of $5 \mu \mathrm{g}$ was just enough to interrupt the oestrous cycle in a normal adult mouse and was equivalent to twice the human dose when calculated on $\mathrm{mg} / \mathrm{kg}$ body weight basis. Rat. Two Groups (six females in each group) fed with 50 and $500 \mu \mathrm{g}$ Enovid, respectively. A 50- $\mu \mathrm{g}$ quantity of Enovid was the minimum dose required to interrupt the oestrous cycle in a normal adult rat. This dose corresponds to twice the human dose on $\mathrm{mg} / \mathrm{kg}$ body weight basis. Rabbit. Two Groups (five females in each group) fed with $500 \mu$ g and $5 \mathrm{mg}$ Enovid, respectively. These doses were comparable to the mouse doses and the rat doses when calculated on $\mathrm{mg} / \mathrm{kg}$ weight basis.

The hormone, dissolved in propylene glycol, was fed directly into the mouth of the animals. In the case of mice and rats, a 1-ml tuberculin syringe, fitted with polyethylene tubing was used. The rabbits were fed with the same syringe without the polyethylene tubing. This ensures that the entire amount of the hormone is ingested by the animals.

Weights of the litters were recorded on Days 2, 5, 10,15 and 20.

\section{RESULTS}

As already reported in the previous communication (Joshi \& Rao, 1966) the offspring of rats which were fed with the compound, showed a lesser weight gain than those born to mothers of the control group. The inhibition was manifest

TABLE 1

GROWTH OF THE RAT LITTERS WHOSE MOTHERS WERE FED WITH ENOVID

\begin{tabular}{|c|c|c|c|c|c|}
\hline \multirow{2}{*}{$\begin{array}{c}\text { Compound } \\
\text { administered } \\
\text { and dose }\end{array}$} & \multicolumn{5}{|c|}{ Weight of the litter $(g)$} \\
\hline & Day 2 & Day 5 & Day 10 & Day 15 & Day 20 \\
\hline Propylene glycol & $\begin{array}{r}35.5 \\
\pm 2.1\end{array}$ & $\begin{array}{c}49 \cdot 2 \\
\pm 2 \cdot 43\end{array}$ & $\begin{array}{r}72.3 \\
\pm 3.7\end{array}$ & $\begin{array}{r}108.3 \\
\pm 7.9\end{array}$ & $\begin{array}{l}143.3 \\
\pm 8.1\end{array}$ \\
\hline $50 \mu \mathrm{g}$ Enovid & $\begin{array}{r}36 \cdot 2 \\
\pm 2 \cdot 4\end{array}$ & $\begin{array}{c}49 \cdot 8 \\
+3 \cdot 18\end{array}$ & $\begin{array}{c}70 \cdot 8 \\
\pm 3 \cdot 13\end{array}$ & $\begin{array}{c}94 \cdot 5^{*} \\
\pm 9 \cdot 2\end{array}$ & $\begin{array}{l}127 \cdot 0^{* *} \\
\pm 10.5\end{array}$ \\
\hline $500 \mu \mathrm{g}$ Enovid & $\begin{array}{c}35 \cdot 9 \\
\pm 2 \cdot 72\end{array}$ & $\begin{array}{c}50.0 \\
\pm 3.49\end{array}$ & $\begin{array}{c}70 \cdot 0 \\
\pm 2 \cdot 77\end{array}$ & $\begin{array}{l}92 \cdot 3 * * * \\
\pm 6 \cdot 9\end{array}$ & $\begin{array}{l}123 \cdot 6^{* * * * *} \\
\pm 8.5\end{array}$ \\
\hline
\end{tabular}

from Day 10 onwards (Table 1). It is a common observation that in the case of the rat, the young do not rely completely on the mother's milk from Day 15 onwards. The young born to the mothers fed with Enovid, however, were not 
able to make up the weight loss observed from Day 10 to Day 15 and were still showing a lesser weight gain on Day 20.

In the case of the mouse, the compound did not bring about an inhibition in growth as is evident by the comparative weight gain of the offspring born to mothers in the control and the experimental groups (Table 2).

TABLE 2

GROWTH OF THE MOUSE LITTERS WHOSE MOTHERS WERE FED WITH ENOVID

\begin{tabular}{l|rccc}
\hline \multirow{2}{*}{$\begin{array}{c}\text { Compound } \\
\text { administered } \\
\text { and dose }\end{array}$} & \multicolumn{4}{|c}{ Weight of the litter $(\mathrm{g})$} \\
\cline { 2 - 5 } & Day 2 & Day 5 & Day 10 & Day 15 \\
\hline Propylene glycol & 7.78 & 11.53 & 18.7 & 24.7 \\
& \pm 0.60 & $\pm 1 \cdot 14$ & $\pm 1 \cdot 14$ & \pm 1.37 \\
$5 \mu$ E Enovid & 7.67 & 11.48 & 19.4 & 25.9 \\
& \pm 0.55 & \pm 1.01 & \pm 1.83 & \pm 2.39 \\
$50 \mu$ g Enovid & 8.28 & 11.85 & 18.7 & $25 \cdot 1$ \\
& \pm 0.28 & \pm 3.2 & \pm 2.57 & $\pm 2 \cdot 15$ \\
\hline
\end{tabular}

In the case of the rabbit, there was too much variation in the initial weights of the litters from any single group of animals $(116 \mathrm{~g}$ to $222 \mathrm{~g})$. Therefore, the weights of the litters on Days 5, 10,15 and 20 were expressed as the percentage of the initial weight, making the comparison between the various groups easier. When compared in this manner an interesting observation was made. The litters

TABLE 3

GROWTH OF THE RABBIT LITTERS WHOSE MOTHERS WERE FED WITH ENOVID

\begin{tabular}{|c|c|c|c|c|}
\hline \multirow{2}{*}{$\begin{array}{l}\text { Compound } \\
\text { administered } \\
\text { and dose }\end{array}$} & \multicolumn{4}{|c|}{ Percentage of initial weight } \\
\hline & Day 5 & Day 10 & Day 15 & Day 20 \\
\hline Propylene glycol & $\begin{array}{c}156 \\
\pm 22 \cdot 34\end{array}$ & $\begin{array}{c}236 \\
\pm 28.93\end{array}$ & $\begin{array}{c}308 \\
\pm 39.64\end{array}$ & $\begin{array}{l}388 \\
\pm 54.83\end{array}$ \\
\hline $500 \mu \mathrm{g}$ Enovid & $\begin{array}{l}150 \\
\pm 8.68\end{array}$ & $\begin{array}{l}260 \\
\pm 21.69\end{array}$ & $\begin{array}{l}363 \cdot 6^{*} \\
\pm 30 \cdot 13\end{array}$ & $\begin{array}{l}467 * * \\
\pm 43.94\end{array}$ \\
\hline $5 \mathrm{mg}$ Enovid & $\begin{array}{c}152.9 \\
\pm 9.75\end{array}$ & $\begin{array}{c}265 \cdot 4 \\
\pm 26.22\end{array}$ & $\begin{array}{r}363^{* * *} \\
\pm 45.92\end{array}$ & $\begin{array}{l}456 * * * * * \\
\pm 65.94\end{array}$ \\
\hline
\end{tabular}

of the Enovid-fed animals showed a much better growth response than those born to control animals. Thus, on Day 15, the litters from the glycol-treated animals were $308 \%$ heavier than the initial weight. The corresponding values for the litters of mothers fed with $500 \mu \mathrm{g}$ and the mothers fed with $5 \mathrm{mg}$ Enovid were 363.48 and $363 \%$, respectively. This difference in the weight gain existed up to Day 20. Thus the percentage weight of the litter from the control group 
was 388 while the corresponding values for $500 \mu \mathrm{g}$ and $5 \mathrm{mg}$ Enovid-treated groups were 467 and 456 , respectively (Table 3 ).

\section{DISCUSSION}

The growth curve of the litter can be employed as an index of either the inhibition or the enhancement of lactation in the mother. The result could be interpreted as a reflection of one or several mechanisms. Some of the important ones that could be considered are:

(1) Change in the prolactin content of the pituitary due to the treatment.

(2) Disturbance in the milk ejection reflex due to the breast engorgement caused by the treatment.

(3) Change in the milk-synthesizing capacity of the breast.

(4) The possibility that the physiologically active compound or its metabolite gets excreted through the milk. The intake of this milk might retard or accelerate the growth of the young, depending on the action of the active constituent which is excreted.

It has already been shown that although Enovid is a potent inhibitor of pituitary gonadotrophins, it does not inhibit prolactin (Kahn \& Baker, 1965). Enovid has been shown to cause extensive proliferation of the alveolar tissue of the mammary gland of the rat (Kahn \& Baker, 1964). It is possible that the engorgement of the breast tissue due to this proliferation may be partly responsible for the observed inhibition in this species. Whether a comparable dose of the compound causes a similar proliferation of the mammary tissue in the rabbit is not known.

It has been suggested that oestrogens reaching the young through the milk could be at least partly responsible for the depression in their growth, except when very low doses are administered to the mothers (Weichert \& Kerrigan, 1942 ; Bloch, 1954). The possibility of the progestational agent reaching the litter through the milk is suggested by a report on feminization of males when the nursing mother was taking the oral contraceptive, Enovid. Laumas (personal communication) could detect radio-activity in the milk of women who were given radio-active norethynodrel. The nature of the metabolite reaching the milk, however, was not established. If this happens in the case of lactating mothers receiving the normal steroid, could it be that, due to the possible difference in the metabolism of Enovid in different species, the nature of the metabolite reaching the offspring in one species enhances the growth while in the other it depresses it? It would be extremely difficult to prove or disprove this assumption.

Also, a difference in the milk-synthesizing capacity of the breast, due to the steroid treatment, has not been ruled out in our studies. This possibility is now being explored.

\section{REFERENCES}

BLoch, S. (1954) Schweiz. med. Wschr. 84, 892; cited by Cowie, A. T. (1961) Milk: The mammary gland and its secretion, Vol. I, p. 184. Eds. S. S. Kovi and A. T. Cowie. Academic Press, New York. 
Jostr, U. M. \& RAO, S. S. (1966) Effect of an oral contraceptive agent on the lactation of rats. Indian 7. exp. Biol. 4, 170.

KAHN, R. H. \& BAKRR, B. L. (1964) Effect of norethynodrel alone or combined with mestranol on the mammary glands of the adult female rat. Endocrinology, 75,818 .

KAHN, R. H. \& BAKER, B. L. (1965) Factors modifying the stimulatory action of norethynodrel on the mammary gland. Endocrinology, 77, 162.

Weichert, C. K. \& KerRigan, S. (1942) Effect of estrogens upon young of injected lactating rats. Endocrinology, 30, 741. 